\title{
Around Arendt's Table: Bureaucracy and the Non-Permanent Members of the UN Security Council
}

\section{Introduction}

Guernica dominates a curved display wall outside the chamber of the United Nations Security Council on the second floor of the Conference Building at the New York headquarters. A tapestry copy of Picasso's out-size painting, Guernica shares its portion of the corridor with the Council's press stakeout area, playing witness to the high drama of high politics. Never was its presence more acutely felt than on $5^{\text {th }}$ February 2003, when it was veiled in UN blue for a ministerial-level meeting to discuss the situation in Iraq. ${ }^{1}$ During that meeting Colin Powell presented a series of aerial photographs in support of his government's case for war. ${ }^{2}$ This rare intrusion of the visual into the august Council chamber recalled an earlier occasion when the world held its breath: Adlai Stevenson's production in October 1962 of photographs showing Soviet military installations in Cuba. ${ }^{3}$ From Nazi aggression, to the Cuban Missile Crisis, to Operation Iraqi Freedom, the military might and great power politics of the Security Council courts public attention.

The resulting perception crowds out more mundane images of the Council, its everyday work, and its less prominent non-permanent members. During its very first term on the Council (201719), Kazakhstan set about reasserting the place of smaller powers on the Council. On $2^{\text {nd }}$ January 2018, the press stakeout area was stage to the inaugural flag-installation ceremony for incoming Council members. The event, which Kazakhstan hopes to become a "meaningful annual tradition", was meant to valorise non-permanent members, and to insist on their equality with other Council members - including the five permanent ones; Britain, China, France, Russia, and the USA.

In effect, however, the flag installation theatrics evoked what Sara Ahmed calls "nonperformative" performance - a way of busily failing to make progress by design, characteristic of institutional bureaucracy. ${ }^{5}$ The red-tape around the press stakeout area took on, in this respect, a very different signification than the police-cordon it otherwise recalls. Taped off within the stakeout area, the flag installation ceremony took as its focal point the stock arrangement of the 15 flags of current Council members - usually a backdrop for press briefings. Each flag occupies

\footnotetext{
${ }^{1}$ See discussion in Anne Orford, "The Destiny of International Law" 17(3) LJIL (2004) 441-476, 458-461

2 UN Doc. S/PV.4701 (5 February 2003)

${ }^{3}$ UN Doc. S/PV.2025 (25 October 1962)

${ }^{4}$ Readers can watch the ceremony here: https://www.youtube.com/watch?v $={ }_{v}$ Cipmdnkn-c . Comments of the permanent representative of Kazakhstan, who compered the ceremony, are also recorded in a letter to the Secretary General, UN Doc. S/2018/254.

${ }^{5}$ Sara Ahmed, On Being Included (Duke UP, 2012)
} 
a holder lodged into one of two portable stands, and are arranged in alphabetical order. The permanent members are not distinguished. Rigorously equal, each flag even droops to precisely the same degree, there being no wind indoors to ruffle them: a triumph of protocol. At the hour of the ceremony, six ambassadors and one minister waited on gaffer-taped marks as each took turn to slot their national flag into one of the vacant spots in the portable pedestals. Eventually every flag was planted, the diplomats assembled for their photo-call, and the two white-gloved security officers turned on their heels and marched away. The event did not symbolise equality, so much as solemnise administrative procedure - a diplomatic changing-of-the-guard.

Kazakhstan's ceremony is a bureaucratic echo of Colin Powell's theatre of war. The different registers of the performances - the emergency and exigency of Powell's, the ritual and protocol of Kazakhstan's - nevertheless both enact authority and status. The exceptionality of great powers is countered by smaller states with an assertion of sovereign equality. The centrality of status is reflected in non-permanent members' strategies to gain influence in the Council. This is easy enough to see in wrangles over its composition, but perhaps less obvious when it comes to working methods reform. In fact, struggles over how the Council works have been framed in terms of the acquisition of new administrative roles, as non-permanent states have pressed for positions as chairs of subcommittees and penholders on agenda items. ${ }^{6}$ Administrative responsibility is no substitute for politics. While accepting that deliberative politics is unlikely in the Council, this article urges non-permanent members to embrace more disruptive working methods as an alternative pathway to influence.

Instead of asserting their individual importance, non-permanent members should focus on making more durable changes to the Council and its operations - ones that last beyond their two-year terms. My analysis draws on the work of Hannah Arendt to argue in favour of the renewing power of diversity. ${ }^{7}$ On this view, non-permanence is not undesirable, it is the essence of incoming members' transformative potential, and a label worth reclaiming. In affirming renewal, I do not suggest that the Council can or does achieve the deliberative mutuality of Arendtian political action. Instead, my focus is on her distinction between labour and work. I argue that laborious administrative roles yield little durable product, and do not affirm plurality, because administrators are anonymous and interchangeable. ${ }^{8}$ Administrative reform reinforces the idea that incoming members are well-behaved guests in the permanent members' house. A

\footnotetext{
${ }^{6}$ In November 2018, the 10 incumbent and the five incoming non-permanent members wrote to the Council pressing for a more equal distribution of responsibilities. Their representative function was one of the arguments they gave in their favour. UN Doc. S/2018/1024 (15 November 2018)

${ }^{7}$ Arendt's work has been used often and in diverse ways by international lawyers. See for example, Jan Klabbers, "Possible Islands of Predictability: The Legal Thought of Hannah Arendt" 20(1) LJIL (2007) 1-23; Susan Marks, "Law and the Production of Superfluity" 2(1) Transnational Legal Theory (2011) 1-24; Alison Kesby, The Right to Have Rights (OUP, 2012); Deborah Whitehall, "People in glass houses: lessons for international law from Margarethe von Trotta's Hannah Arendt" 2(2) LRIL (2014) 329-353; Ioannis Kalpouzos and Itamar Mann, "Banal Crimes against Humanity: The Case of Asylum Seekers in Greece" 16(1) Melbourne Journal of International Law (2015) 1-36; Ayça Cubukçu, "On the Exception of Hannah Arendt" 15(3) Law, Culture and the Humanities (2019) 684-704

${ }^{8}$ Hannah Arendt, On Violence (Harvest, 1969), 81
} 
more hands-on and less business-as-usual approach could make non-permanent membership a force for renewal and transformation.

The first part of the article reconsiders the implications of non-permanence in Security Council membership - the good, and the bad. The second part draws on Arendt's insights to analyse working methods reform as a pathway to influence and renewal. The article ends by reflecting on the transformative potential of spontaneity and being in-the-way.

\section{Implications of Impermanence}

Impermanence is usually treated as a barrier to influence, which can be removed either by seeking constitutional parity with the permanent members, or by achieving an operational redistribution of responsibilities. This contribution thinks through the second of these strategies for influence, using ideas Hannah Arendt elaborated in The Human Condition to do so. In this respect it follows Jan Klabbers in drawing on Arendt as a "source of inspiration" rather than a "fount of wisdom". ${ }^{9}$ In particular, it does not find in Arendt's work a blueprint for political action or deliberative democracy in the Security Council.

Arendt shows us that while impermanence seems like a barrier to individual influence, it could be the key to transforming the Security Council. Although the Council will never be a space of appearance for a global polis, "the space where I appear to others as others appear to me", ${ }^{10}$ it is nevertheless ripe for change. Premised on inequality, and deliberately designed as an elite body of strong-man states poised to take decisive action against aggressors, it was not made for mutual recognition and deliberative politics. ${ }^{11}$ But today its strongman credentials are at odds with the world. The Council is a microcosm of a world that no longer exists - one in which Britain and France were Great Powers, Germany and Japan were enemies of peace, and European colonisers still ruled much of the world. The sovereign inequality of the Council, with five Allied Powers as its permanent members and ten rotating non-permanent seats, is increasingly difficult to defend on grounds of functional proficiency. Rather than a positive vision of deliberative politics, then, this article proffers a negative one - the end of great power politics.

Back in 2005 heads of state and government pledged "early reform of the Security Council... in order to make it more broadly representative, efficient and transparent and thus to further enhance its effectiveness and the legitimacy and implementation of its decisions", but its composition is yet to change. ${ }^{12}$ Working methods reform emerged in 2006 as a more feasible alternative to composition reform. At present, however, it is hamstrung by being rendered in

\footnotetext{
9 Jan Klabbers, "Hannah Arendt and the Languages of Global Governance" in Marco Goldoni and Chris McCorkindale, Arendt and the Law (Hart, 2012), 229

10 Arendt, The Human Condition, 198-199

${ }^{11}$ Isobel Roele, “The Vicious Circles of Habermas' Cosmopolitics” 25(3) Law and Critique (2014) 119-229. cf. Ian Johnstone, "Security Council Deliberations: The Power of the Better Argument" 14(3) EJIL (2003) 437; Ian Johnstone, "Legislation and Adjudication in the UN Security Council: Bringing Down the Deliberative Deficit" 102 AJIL (2008) 275

12 UN World Summit Outcome Document, UN Doc. A/Res/60/1 (2005), para. 153
} 
terms of status. In November 2018, non-permanent members wrote to the Council president demanding greater parity of status through the redistribution of penholderships and chairpersonships. ${ }^{13}$ This framing has lumbered non-permanent members with much more responsibility and little more control. Arendt helps rethink non-permanent membership in terms of activity, rather than status. Instead of seeing responsibilities as badges that can be won, we focus on how non-permanent members might change the Council. Such change, moreover, depends not on becoming more like the permanent members through training programmes that enable new members to "hit the ground running", but by new members insisting on each their particularity.

a) Impermanence and renewal

The UN Security Council is a "political organ" par excellence. ${ }^{14}$ Its particular brand of politics is identified with out-and-out Realpolitk, distinguishing it from the comparatively deliberative General Assembly. On this view, power is political capital - military, diplomatic, or moral - that one either possesses or lacks. Arendt offers an alternative view that associates politics with freedom rather than control. Here power is a matter of potential rather than possession. It inheres in the human capacity to act, and more precisely to begin something new. Moreover, for Arendt, politics is participatory and collective - it is about "being together". The Council is not political in this sense. It is a space dominated by the P5, whose institutional privilege and political capital alienate the ten rotating non-permanent members from the organ.

The UN Charter famously privileges the five permanent members of the Council - Britain, China, France, Russia, and the USA - with a veto power over decisions. ${ }^{15}$ These states also enjoy considerable privileges that stem from the fact of their permanence. Michael Reisman vividly likened the Council to a matryoshka doll, which contains "ever-smaller 'mini-Councils', each meeting behind closed doors without keeping records, and each taking decisions secretly". ${ }^{16}$ The P5, P3 and P1 dominate the body, marginalising the ten non-permanent members, and the broader the UN membership as a whole. ${ }^{17}$ This mode of politics is action-oriented, not discursive - geared to providing "prompt and effective action". ${ }^{18}$ Council politics are also seen as very self-interested, ${ }^{19}$ rendering politics a matter of "people [being] only for or against other people". ${ }^{20}$

\footnotetext{
13 UN Doc. S/2018/1024 (15 November 2018)

${ }^{14}$ As Judge Schwebel said, "the Security Council is a political organ which acts for political reasons" rather than legal ones. Military and Paramilitary Activities in and against Nicaragua (Nicaragua v. USA) Merits, ICJ Reports, 1986, dissenting opinion of Judge Schwebel, 290, para. 60

${ }^{15}$ UN Charter, Article 27(3)

${ }^{16}$ W. Michael Reisman, "The Constitutional Crisis in the United Nations” 87(1) AJIL (1993) 83-100, 85. Cf.

${ }^{17}$ Mahubani, “The Permanent and Elected Council Members”, 256-257

${ }^{18}$ UN Charter, Article 24(1)

${ }^{19}$ Adam Roberts and Dominik Zaum, Selective Security: War and the United Nations Security Council Since 1945

(Routledge, 2008)

${ }^{20}$ Arendt, The Human Condition, $2^{\text {nd }}$ ed. (University of Chicago Press, 1998), 7
} 
Domination and self-interest are not the Council's only faults: it is also thoroughly

bureaucratised. Bureaucracy is entirely in keeping with the UN's modus operandi, ${ }^{21}$ and has crept in both as a means of curtailing the permanent members' power (for instance in the requirement that the Council report on its work, ${ }^{22}$ and consult more widely ${ }^{23}$ ), and as a means for the body to exercise power (the proliferation of subsidiary organs, ${ }^{24}$ and the use of monitoring and reporting mechanisms testify to this ${ }^{25}$ ). Contrary to its popular image, the Council is not always in emergency mode. An increasing proportion of its business concerns mandate renewals, expert reports, horizon-scanning, and liaising with other global actors. ${ }^{26}$ For Arendt, bureaucracy is violent, too. Famously describing it as "rule by nobody", she pointed out that it makes everyone equally powerless without the need for a tyrant. Bureaucracy is indifferent to human beings and denies us our "faculty of action", which rests, she says, on the ability "to embark on something new". ${ }^{27}$ Bureaucracy is "anti-politics" in Arendt's work, to use Klabbers's apt term. ${ }^{28}$

Arendt primarily talked about the stifling effect of bureaucracy on political action in terms of responsibility, because it alienates men from their actions. Bureaucracy is also stifling because it demands more of the same. It generates an ocean of certainty, to adapt Arendt's famous image. Here, rule is "misused to cover the whole ground of the future and to map out a path secured in all directions". ${ }^{29}$ In this respect, bureaucracy is inimical to freedom conceived of as "the spontaneous beginning of something new". ${ }^{30}$ This is precisely what has happened to the nonpermanent members of the Security Council. The yearly intake of five new members brings with it a promise of renewal, which is systematically neutralized by channeling the activity of new members into bureaucratic avenues, and by socializing them into established administrative patterns.

Every January, five new members enter the Security Council, and five old ones leave. Although we talk about the Council in terms of its permanent and non-permanent members, in practice there are several groups: Permanent members, sophomore non-permanents, freshman nonpermanents, recent graduates, incoming members elect, and candidates for future membership.

\footnotetext{
21 As Anne Orford shows in International Authority and the Responsibility to Protect (CUP, 2011) 94-97. See also, my Articulated Security: The United Nations and its Infra-Law (CUP, forthcoming).

22 UN Charter, Article 24(3)

${ }^{23}$ The "Green Book", of Working Methods Handbook contains multiple entries relating to consultations and dialogues. Available at: http://www.un.org/en/sc/about/methods/

24 UN Charter, Article 29

25 See e.g. Isobel Roele, "Disciplinary Power in the UN Counter-Terrorism Committee" 19(1) Journal of Conflict and Security Law (2014) 49-84

${ }^{26}$ A sense of the vast body of rolling business can be gained by reading the monthly digest of the Security Council Reporting and Mandate Cycles, prepared by the Security Council Secretariat Branch of the Department of Political and Peacebuilding Affairs. The 2019 edition, published in December 2018, runs to 113 pages. Available at: https://www.un.org/securitycouncil/sites/www.un.org.securitycouncil/files/general/reportingandmandatecycles 1 22018.pdf

${ }^{27}$ Hannah Arendt, On Violence (Harvest, 1969), 81-82

${ }^{28}$ Jan Klabbers, "Possible Islands of Predictability: The Legal Thought of Hannah Arendt” 20(1) LJIL (2007) 1-23, 11

29 Arendt, The Human Condition, 244

30 Arendt, The Human Condition, 234
} 
The dynamism of Council composition involves a sizeable portion of the wider UN membership, which at least gestures towards inclusivity. In this sense, the short two-year term served by non-permanent members is a potential source of renewal for the Council. ${ }^{31}$ It suggests a glimmer of natality, "the new beginning inherent in birth" which makes action, and therefore politics, possible. ${ }^{32}$

Newness and difference are connected for Arendt. Pluralistic politics depends on the renewing effect of birth and the potential for spontaneity it brings. For her, political action "corresponds to the human condition of plurality, to the fact that men, not Man, live on the earth and inhabit the world". ${ }^{33}$ What does Arendt understand by plurality? It means "the presence and acting of others": being together. ${ }^{34}$ This connotes gathering in a place, not abstract collectivity. Here, difference does not exclude identity because actors inhabit a shared world. Diverse individuals "can retrieve their sameness, that is, their identity, by being related to the same chair and the same table". ${ }^{35}$ The Council's political authority resides in the gathering of its members around its famous horseshoe table, not in blitzkrieg reactions or unanimous votes. Regular renewals of the Council membership make it possible to bring new configurations of states around the Council table - ones with particular experience in regional, thematic and situational issues on the Council's agenda. Arendt offers a new way to think of plurality, in terms different from geographical representation and security savoir-faire, the terms on which Council elections are usually conducted. ${ }^{36}$

In Arendt's work, plurality is the condition of public sphere, the existence of which is controversial on a global scale - even within the internationalist walls of the UN. The UN is a space of alienation, where state actors lack the common sense of a shared outside world, and meet one another in a state of splendid sovereign isolation. Political action in Arendt's sense is not the only way that the UN might be something more than war-by-other-means, a space for states to duke out their differences by exchange of letters. There is a gap between deliberative politics and Great Power rule that can be filled negatively by refusing what is there, rather than offering something new. This politics of difference also rests on the spontaneous newness that non-permanent membership brings - for the disruptive effects of renewal. This brings an Adornian edge to Arendt in the form of non-identity thinking. ${ }^{37}$

The obvious objection to this valorization of polyvocality and spontaneous objection is that security is all about order and decision. Disruptive activity may slow the pace of reaction in emergency situations, and would render unanimity elusive. The Council's univocal and

\footnotetext{
31 UN Charter, Article 23(2)

32 Arendt, The Human Condition, 9

33 Arendt, The Human Condition, 7

34 Arendt, The Human Condition, 237

35 Arendt, The Human Condition, 209

35 Arendt, The Human Condition, 67

${ }^{36}$ UN Charter, Article 23(1)

${ }^{37}$ Theodor Adorno's negative dialectics changed the direction of conceptuality, "to give it a turn toward nonidentity", Negative Dialectics (trans. E. B. Ashton) (Continuum, 1973), 12
} 
unequivocal decisions may show Schmittian resolve ${ }^{38}$ but it is an unsavoury model of authority. Arendt recognized that action leads to unpredictability, but concluded that,

"It is the obvious short-range advantages of tyranny, the advantages of stability, security, and productivity, that one should beware, if only because they pave the way to an inevitable loss of power" ${ }^{39}$

For Arendt, politics - the action of being together, and talking about how we might be together in the future - is a matter of tempering renewal with predictability, without letting the latter devolve into tyranny. Given its composition, mandate and the lack of constitutional limits to its power, the Council seems poised on the brink of tyranny, or in the more current phrase hegemony. ${ }^{40}$ Even in more positive narratives, the Council is seen as a bastion of strong leadership in an unstable world, and we might see the Charter as mandating a cadre of big men phalanxed by yes-men.

Still, as non-traditional security challenges like pandemic disease, transnational organised crime and climate change have begun to populate the Council's agenda, and as the human security discourse has taken hold in the UN, it is increasingly difficult to affirm a view of the Council-asstrongman. As Marrti Koskenniemi famously imagined, such a comprehensive conception of security lets the police into the temple. ${ }^{41}$ The image contains the wrong kinds of both certainty and unpredictability: the certainty of domination and the unpredictability of how it lashes out. The tension between the five permanent members - especially between the three Western states on one side, and Russia and China on the other - are the most commonly cited brake on this ugly concatenation. Great power, on this view, can only be countered by great power. This discourse is echoed by the G4 group of states who support one another's permanent membership of the Council. Brazil, Germany, India, and Japan. ${ }^{42}$ All four states premise their case for permanent inclusion on their economic, institutional and regional clout. They seek to renew the Council, in other words, by imitating the exceptional status of the present incumbents.

\section{b) Impermanence as a barrier to influence}

As well as suggesting a positive side to impermanence, Arendt's work also helps dig down into the more familiar downsides. This sub-section uses her distinction between work and labour to

\footnotetext{
38 Anna Hood, “The United Nations Security Council's Legislative Phase and the Rise of Emergency International Law-Making" in Kim Rubenstein and Hitoshi Nasu, Legal Perspectives on Security Institutions (CUP, 2015)

39 Arendt, The Human Condition, 222

${ }^{40}$ For criticisms of the Council on similar grounds, see: Nico Krisch, "International Law in Times of Hegemony: Unequal Power and the Shaping of the International Legal Order" 16(3) EJIL (2005) 369-408; José Alvarez, "Hegemonic International Law Revisited" 97(4) AJIL (2003) 873-888

${ }^{41}$ Martti Koskenniemi, "The Police in the Temple: Order, Justice and the UN; A Dialectical View" 6(3) EJIL (1995) 325-348

42 A draft General Assembly resolution for Security Council reform was sponsored by all four states, among others. UN Doc. A/59/L.64 (2005)
} 
recast some of the challenges faced by Council members. I identify three: the brevity of their terms; their relative institutional knowledge; and their lack of belonging.

The first barrier to influence is the brevity of membership. Making a durable difference in the Council, one that outlasts a member's term, is difficult to do in the space of two years especially given that the Charter does not allow consecutive terms. ${ }^{43} \mathrm{New}$ members arrive in medias res, faced with a pre-existing agenda and programme of work. Moreover, few situations on the Council's agenda can be squared away within two years - even if an incoming member is upto-speed from day one. Non-permanent members rarely get to see an issue through to completion, and usually inherit someone else's strategy for dealing with it.

As part of their reform agenda, the Working Group on Documentation and Other Procedural Questions have sought to ensure that incoming members can make the most of their terms. One initiative has been to bring forward elections from October to June, so that members elect have six months to prepare, rather than just two. ${ }^{44}$ Another innovation has been to give incoming states privileges, including observing Council meetings (subject to the objection of incumbent members). ${ }^{45}$ The longer lead-in time gives new members the chance to undertake training and to familiarise themselves with Council procedures, and the formidable number of items on its agenda. In effect, the brief terms non-permanent member states serve are a mad dash. ${ }^{46}$ The frenetic speed of Council activity is not only a product of the Charter imperative for "prompt" action, or a result of the time-poverty characteristic of highly bureaucratised environments. It is also a matter of mood. Training and socialisation processes reinforce the feeling. An orientation workshop for new members run by Finland is called "hitting the ground running", and there is immense pressure on new members to keep up, fit in and fall into step with the pace set by the permanent members.

States have sought ways of counteracting the brevity of their terms. Some make it their business to sit on the Council as much as possible. Japan, for instance, has served 11 terms. It is among a number of states which have found ways to keep-its-hand-in, even when off the Council. Japan has been particularly active, in this regard, in pressing forward with working methods reform. Other states, including Finland, Sweden and Turkey, also involve themselves with the Council even when they are not member states. Finland provides the orientation training session; and Turkey and Sweden, for instance, have hosted annual retreats for the Security Council. ${ }^{47}$ If states want to have lasting effects, new members must have "the tactical dexterity to play with the P5", as John Langmore and Jeremy Farrall put it in their analysis of Australia's 2013-14 term on the

\footnotetext{
43 UN Charter, Article 23(2)

44 UN Doc. S/2016/619 (15 July 2016)

45 UN Doc. S/2017/507, paras 140-142

46 Below, at 3(b)

${ }^{47}$ Turkey in cooperation with the International Peace Institute. Sweden held the retreat in April 2018 in Dag Hammarskjold's private estate. See: https://www.government.se/articles/2018/04/note-to-the-press-on-thesecretary-generals-security-council-retreat-in-backakra-sweden/
} 
Council. ${ }^{48}$ Australia's ability to deploy such dexterity has enabled it to effect Council business even when it is not serving on the body, especially in its work as part of the Contact Group on Timor Leste. ${ }^{49}$

Still, being involved on the fringes does not guarantee these states a say in core Council business. The Council operates a conveyer-belt system, as incoming members replace outgoing ones with little regard to the particularity of either. ${ }^{50}$ The important thing is that a state is competent, regardless of any idiosyncratic insights it might offer. When it comes to administration, the Council is as much of a meritocracy as the nineteenth century bureaucracies described by Max Weber, and new states are funnelled into training sessions which enable them to seamlessly take the reins from outgoing colleagues. The interchangeability of administrative roles, we might say is an instance of rule by anybody, if not quite "rule by nobody" as Arendt described totalitarian bureaucracy.

A second issue for non-permanent members is that, compared to the permanent members, they have less institutional knowledge; both in terms of day-to-day savoir faire and in terms of longterm memory. Kishore Mahubani affirmed this, quoting the permanent representative of Cameroon: "The presence of permanent members in an institution is in itself a decisive advantage". ${ }^{51}$ However, as we shall see, the extent to which this is the case differs greatly depending on the delegation. There is a world of difference between non-permanent members of the Council in terms of their delegation size, political clout, economic heft, local knowledge, and institutional memory. It would be misguided to assume that increased non-permanent involvement tout court makes the Council more diverse and pluralistic, as many of the most active non-permanent members belong to the Western Europe and Others Group in the UN. ${ }^{52}$

For some elected members serving on the Council is a daunting prospect. ${ }^{53}$ However, it is a much less daunting when one works in a well-staffed mission. The US mission is the largest. The UK's mission is half the size: the UN Blue Book lists around 45 ambassadors, counsellors, secretaries and attachés. ${ }^{54}$ Norway, running for election in 2020-21, lists an 18-strong team, slightly fewer than Khazakstan (20). These lists do not, of course, tell the whole story. However, the individuals seconded to the UN to bolster a mission for the duration of a state's Council membership lack the deep institutional knowledge of their colleagues who work in the institution

\footnotetext{
48 John Langmore and Jeremy Farrall, "Can Elected Members Make a Difference in the UN Security Council? Australia’s Experience in 2013-2014” 22 Global Governance (2016), 59-77, 68

49 Jeremy Farrall and Jochen Prantl, "Leveraging diplomatic power and influence on the UN Security Council: the case of Australia" 70(6) Australian Journal of International Affairs (2016) 601-612. For more on Groups of Friends and Contact Groups, see below at, s. 3(b)

50 The November 2018 letter from the non-permanent members urges the Council to recognise and make use of their regional and thematic experience and expertise. UN Doc. S/2018/1024 (15 November 2018)

${ }^{51}$ Mahubani, "The Permanent and Elected Council Members", 253 (quoting UN Doc. S/PV.4677 (20 December 2002))

52 These are formal regional groupings in the UN system, and are listed on the UN's Department for General Assembly and Conference Management. Available at: https://www.un.org/depts/DGACM/RegionalGroups.shtml

53 Sievers and Daws, SC Procedure, 130. The transition into the Council is "brutal".

${ }_{54}$ Available at: https://protocol.un.org/dgacm/pls/site.nsf/BlueBook.xsp
} 
full-time. The institutional savoir faire and personal contacts of mission staff - particularly the allimportant political coordinator - can determine the success of a term. Not only the size, but also the experience and training of a mission, then, affect a state's ability to adjust to the breakneck high politics of the Council..$^{55}$

The ease with which an incoming member navigates the Council also depends on the number of terms it has served. Germany and Belgium (both part of the 2019 intake), have already served 5 terms. By contrast, of the Council members at the time of writing, Kazakhstan (2017-18) and Equatorial Guinea (2018-19) have no prior experience, and neither does newly elected Dominican Republic (2019-20). Frequent fliers have a rich institutional memory especially when they make a study of the Council. This is literally the case for Japan, which in 2006 produced a working methods manual for the Council, now known as The Green Book. ${ }^{56}$

Steps have been taken to remedy deficits in institutional knowledge. Member states receive training sessions from various providers, ${ }^{57}$ and the Security Council Affairs Division of the Secretariat's Department of Political Affairs also provides support. Amongst other things, the Division has responsibility for the Council's Repertoire of Practice. States, however, have been unimpressed with this offering, and the Division has been criticised in the UN's internal review processes for the lack of support it provides to new members. ${ }^{58}$ The Repertoire has taken a lot of flak from states, which have asked instead for more information about the Council's rules and procedures. $^{59}$

The third barrier to influence is more inchoate, and relates to another way in which new members may be daunted: lack of a sense of belonging. In more than one way, the permanent members own the Security Council: it is their house, which others visit at their pleasure. The Dumbarton Oaks powers claim credit for creating the UN in the first place, and the Charter gives them privileges as permanent members. They not only know-the-ropes, they designed the ropes. Furthermore, the UN is situated in New York, and held its first meeting in London. Although it has met elsewhere - including Addis Ababa, Geneva, Nairobi, Panama City and Paris, and although its delegates sometimes undertake fieldtrips, ${ }^{60}$ its centre of gravity is firmly planted in the global North.

55 "Informal Groups of States and the UN Security Council" 59(3) International Organization (2005) 559-592, 56970

${ }^{56}$ The Handbook is periodically updated, and advertised on the Council website. Available at: https://www.un.org/securitycouncil/content/introduction

${ }^{57}$ Discussed in brief below, at 3(b)

58 OIOS, Audit Report: The Security Council Affairs Division in DPA (October 2010), Assignment No. AP2010/560/01. Available at: https://usun.state.gov/sites/default/files/organization pdf/159757.pdf

${ }^{59}$ UN Doc. E/AC.51/2007/2/Add.2, para. 15 and E/AC.51/2007/2/Add.2, para. 12

${ }^{60}$ Its first fieldtrip to Cambodia and Viet Nam was in the summer of 1964, though in recent years visits have proved more difficult to organise, according to Security Council Report, "Security Council Visiting Missions" (14 May 2018). Available at: https://www.securitycouncilreport.org/un-security-council-working-methods/visitingmission.php 
The control exerted by the permanent members over the Council is much remarked. ${ }^{61}$ As Mahubani put it "while the P-5 have been given power without responsibility; the E-10 have been given responsibility without power". ${ }^{2}$ The sense that the Council is a sort of autonomous region within the UN plays out in frequent antagonisms between the Council and the Assembly on the one hand, and the Council and the Secretariat on the other. ${ }^{63}$ If joining the Council is treated as temporary membership of an elite club, to enter its doors is to enter a rarefied worldwithin-a-world. The relatively recent practice of holding monthly meetings for the ambassadors and for political coordinators of non-permanent members is a sensible corrective for the daunting prospect faced by new missions, but it does not necessarily tackle the alienation of the elected members. ${ }^{64}$ Instead, it tends to reinforce Reisman's Matryoshka doll image by producing another closed circle within the Council.

Of course, not all delegations experience this alienation in the same way. Some 60 states are absolute strangers to the Council, having never taken a seat around its table. ${ }^{65}$ This is often a question of size (Micronesia, Liechtenstein) or money (Kiribati, Lao and Lesotho are all currently on the UN's list of Least Developed Counties), ${ }^{66}$ and may have as much to do with a state's ability to field a sufficiently robust mission, as its formal contribution to international peace and security. That said, the number of never-members continues, hearteningly, to decline. At the time of writing, the Council has welcomed several first-timers, including the Dominican Republic and Kazakhstan. For other states - particularly those active in the Non-Aligned Movement - maintaining a certain distance from the Council, as currently composed, is a badge of pride. Among the states which seek permanent seats of a reformed and expanded Security Council, India and Brazil - both Non-Aligned Movement stalwarts - have distanced themselves from the powers-that-be in the Council. During India's seven terms and Brazil's 10, both states have often been outspoken in their doubts about the Council's activities, a critical distance they maintain by speaking out at meetings even when they are not serving on the body. ${ }^{67}$

Indeed, the Council affords various opportunities for states outside its orbit to involve themselves in its work. Troop and police contributing countries, for example, are accorded privileges of consultation not available to the general membership. ${ }^{68}$ Moreover, any state can,

\footnotetext{
${ }^{61}$ Nico Krisch, "International Law in Times of Hegemony: Unequal Power and the Shaping of the International Legal Order" 16(3) EJIL (2005) 369-408; José Alvarez, "Hegemonic International Law Revisited” 97(4) AJIL (2003) 873-888,

${ }^{62}$ Kishore Mahubani, “The Permanent and Elected Council Members” in D.M Malone (ed.) The UN Security Council (Lynne Rienner, 2004), 256

${ }^{63}$ Under Kofi Annan the relationship between the permanent members and the Secretariat could be frosty. Annan strongly supported the body's reform. Interventions: A Life in War and Peace (Penguin, 2012), Ch. IV

64 “Ten Elements for Enhanced E10 Coordination and Joint Action", September 2018. Sievers and Daws, SC

Procedure: Online Update to Ch. 3, s. 3 (10 December 2018). Available at: https://www.scprocedure.org/chapter-3section-3i

${ }^{65}$ The UN publishes a list. Available at: http://www.un.org/en/sc/members/notelected.asp

${ }^{66}$ https://www.un.org/development/desa/dpad/least-developed-country-category/ldcs-at-a-glance.html

${ }^{67}$ UN Charter, Article 32; Security Council Provisional Rules of Procedure, Rules 37 and 38 (UN Doc. S/96/Rev.7 (1982))

${ }^{68}$ UN Doc. S/2017/507
} 
subject to members' consent, observe Council meetings, even informal Arria meetings - though most Council business takes place in the private informal-consultations-of-the-whole, behind closed doors. Interested states can, in theory, follow the Council's programme of work and agenda through the UN Journal and various other publications undertaken in the name of transparency. In practice, the Council's breakneck speed outpaces this mode of engagement. In any case, efforts to improve transparency do not address the fundamental feeling that those without a permanent place in the Council are outsiders looking on. ${ }^{69}$

Some states have attempted to increase their influence in more creative ways. This article opened with Kazakhstan's attempt to institute a flag installation ceremony - as instant tradition-making. Other states have been equally ingenious in finding ways of leaving a mark on the body. Three states - Germany, Norway and Russia - have asserted their ownership over the Council in a material way. ${ }^{70}$ From approximately 2008 until 2015 the UN campus at Turtle Bay was renovated as part of the Capital Master Plan - including the Council's three dedicated rooms: its Chamber, its Consultations Room, and its Quiet Room. This involved both practical improvements, such as updating the air-conditioning and wifi, and refurbishing the translators' booths, and aesthetic choices. Germany's contribution to the Quiet Room, for instance, included Walter Knoll furniture, a tasteful colour scheme, and a mural of a Teutonic forest.

Norway made no aesthetic changes to the Council Chamber, which it designed and created in 1952, at the behest of Secretary General Trygve Lie. ${ }^{71}$ As Ban Ki-moon put it at the inauguration of the room, "if... Trygve Lie ... were with us today, I am sure he would feel quite at home ... Perhaps the only thing he would miss would be the ash trays!". ${ }^{72}$ The Chamber was originally designed by architect Arnstein Arneberg to reflect, as Norway's Crown Prince recognised when he announced Norway's candidacy for a seat on the Council for the 2021-22 biennium, "Norwegian craftsmanship and values". ${ }^{73}$ Per Krohg's painting, Else Poulsson's wallpaper and curtains, and the blue delegates' chairs designed by Finn Nilsson and made by cabinetmaker Johan Fr. Monrad constitute the material world of the Council chamber. At the first meeting of the Council in its permanent home on $4^{\text {th }}$ April 1952, the President thanked "all those, both high and humble, who have by their joint effort built for us a beautiful place in which to serve and

\footnotetext{
${ }^{69}$ There is an increasing body of writing questioning the value of transparency. Haridimos Tsoukas, "The Tyranny of Light" 29(9) Futures (1997) 827-843; Marilyn Strathern, “The Tyranny of Transparency" 26(3) British Educational Research Journal (2000) 309-321; Andrea Bianchi, Anne Peters (eds), Transparency in International Law (CUP, 2013); Fleur Johns, “The Deluge” 1(1) LRIL (2013) 9-34

${ }^{70}$ The materiality of international law is explored in Jessie Hohmann and Daniel Joyce, International Law's Objects (OUP, 2018 - forthcoming)

${ }^{71}$ Ingeborg Glambek, "The Council Chambers in the UN Building in New York" 15 Scandinavian Journal of Design History (2005) 8-39

${ }^{72}$ Ban Ki Moon, "Remarks at the inauguration of the renovated Security Council Chamber" (16 April 2013). Available at: https://www.un.org/sg/en/content/sg/speeches/2013-04-16/remarks-inauguration-renovatedsecurity-council-chamber

${ }^{73}$ Speech given by His Royal Highness The Crown Prince at the launch of Norway's candidacy for a seat on the United Nations Security Council 2021-22, New York 22 June 2018. Available at: https: / $/$ www.kongehuset.no $/$ tale.html?tid $=163838 \&$ sek $=26947 \&$ scope $=27248$
} 
work for the highest interests of peace and security in the world". ${ }^{74}$ Norway's durable contribution is not be replicable by other states, but it illustrates the role non-permanent members can have in making the Council's world - rather than only inhabiting it.

Norway is intensely proud of the Council Chamber, and subverts its non-permanent status by playing on the permanence of its creation. The website of its permanent mission to the UN, for instance, boasts an article about the Chamber entitled "Norway's permanent Security Council place", 75 and one of its Flickr albums dedicated to the Council carries the description "Norway doesn't have a permanent seat in the UN's Security Council. The Security Council Chamber's chairs ... however, are all Norwegian" ${ }^{76}$ Its contribution to the material form of the Council gives Norway a sense of ownership, if not belonging, in the organ. Its diplomats may not always have a voice in the Council, but its craftsmen ensure that Norway keeps its hand in.

How does Arendt help us understand these three barriers to influence - brevity of term, lack of institutional knowledge, and sense of belonging - differently? Key to the answer is her distinction between work and labour. ${ }^{77}$ These two activities are prior to political speech and action, which we met in the previous section. Work and labour are differentiated by their durability and futility, respectively. Labour is needed to sustain life: its products are no sooner made than consumed. Work, by contrast, makes the shared human world we inhabit - works outlive their creators. ${ }^{78}$ By engendering "the worldly stability of the human artifice", work makes politics possible. ${ }^{79}$ It creates a physical place for human being-together, which could become the conceptual space of the polis if it is one where human beings can "distinguish themselves instead of being merely distinct". ${ }^{80}$

The three barriers to influence appear in a different light if we think of them in terms of work. The non-permanent members cannot leave themselves behind in the Council, but they can leave an enduring mark. Arendt's distinction casts Norway's perhaps superficial-seeming contribution in a new light. The men and women who made the objects in the Chamber - including the famous horseshoe table - created a shared space is indispensable to politics. Arendt recognized the tendency to downplay such contributions. The modern world, she wrote, regards "everything beyond the enforcement of law and order as "idle talk" and "vain-glory"'. ${ }^{81}$ On the contrary, the importance of sitting around the same table in the same chairs should not be underestimated. She explained,

\footnotetext{
74 UN Doc. S/PV.575 (4 April 1952), 2

75 Available at: https://www.norway.no/en/missions/un/norway-and-the-un/norways-rich-history-at-theun/norways-permanent--place-in-the-security-council/

76 Available at: https://www.flickr.com/photos/norwayun/sets/72157631290329704

77 The distinction has been criticised, especially by Seyla Benhabib, The Reluctant Modernism of Hannah Arendt

(Rowman \& Littlefield, 2003), esp. 130-133

${ }^{78}$ Arendt, The Human Condition, 136-139

${ }^{79}$ Arendt, The Human Condition, 126

80 Arendt, The Human Condition, 209

80 Arendt, The Human Condition, 67

81 Arendt, The Human Condition, 159
} 
"To live together in the world means essentially that a world of things is between those who have it in common, as a table is located between those who sit around it; the world, like every in-between, relates and separates men at the same time" ${ }^{82}$

Non-permanent member strategies to increase their influence should aim to produce durable contributions, not just shoulder responsibilities. Focus is often on outcome documents. The Council's main work product is not world peace, but outcome documents. ${ }^{83}$ Although characteristic of a "bygone technocratic universalism", outcome documents and the meetings which produce them are the centrepiece of non-permanent members' efforts to increase their influence in the Council. Although bureaucracy is a technology in which we have lost faith, ${ }^{84}$ as Riles explains, it is nevertheless "one that we already know how to use". ${ }^{85}$ Non-permanent members cannot, however, use the tools of bureaucracy to break into the world of high politics. Bureaucracy is not a condition of political action in Arendt's sense. On the contrary, it is deadening. It results in the zombified "non-performative" performance identified by Ahmed, whereby going through the administrative motions substitutes for real change. ${ }^{86}$

Arendt's distinction between labour and work offers a critical tool for reassessing some of the strategies states have undertaken to increase non-permanent members' influence. Many of these efforts have been aimed at making the state itself a permanent fixture in the Council. Arendt's association of political action and renewal cast doubt on the enlivening effects such composition reform could attain. When seen through an Arendtian lens, a large tranche of other efforts those which focus on the distribution of work and the training of new members - are more reminiscent of futile labour than durable work. It is to this second group of reform efforts working methods reform - that I now turn.

\section{Critique of Working Methods Reform}

Great efforts have been made to improve the lot of non-permanent members under the rubric of working methods. ${ }^{87}$ The initiative was initially taken by a permanent member - France. It produced an aide mémoire, a form designed to transmit established practices, rather than modify them. ${ }^{88}$ Since 2006 the question of working methods reform has been taken on non-permanent members, who have leveraged working methods reform to pave a pathway to influence. Initiatives by the "small five" (Costa Rica, Jordan, Lichtenstein, Singapore and Switzerland) and Japan to reform of the Council's (still) Provisional Rules of Procedure, ${ }^{89}$ metamorphosed into

\footnotetext{
82 Arendt, The Human Condition, 52

${ }^{83}$ Below, at 3(b)

${ }^{84}$ See generally David Graeber, The Utopia of Rules (Melville House, 2015)

85 Annelise Riles, "Outputs: the promises and perils of ethnographic engagement after the loss of faith in transnational dialogue” Journal of the Royal Anthropological Institute (2017) 183-198, 187

${ }^{86}$ The context of Ahmed's discussion is university commitments to diversity, see especially Ch. 4

${ }^{87}$ See generally, Joanna Harrington, "The Working Methods of the UN Security Council: Maintaining the Implementation of Change” 66(1) ICLQ (2017) 39-77

88 UN Doc. S/1994/1279

${ }^{89}$ The Non-Aligned Movement has long pressed for the rules of procedure to be formalised.
} 
efforts to reform the Council's working methods at operational level. On its face, working methods reform is a potentially much more progressive and inclusive strategy for making other voices heard in the Council, as it focuses on transforming the way the Council works, rather than elevating the status of specific states to match the P5. In practice, however, the strategy has failed because administrative roles have been taken as indicators of importance, but are extremely difficult to leverage in order to leave lasting effects on the Council. This is because, as Arendt's insights reveal, administrative activity is labour rather than work.

The institutional vehicle for working methods reform are Notes of the President, which are usually reserved for procedural matters like the appointment of subcommittee chairs and renewing the mandates of working groups. They are archetypal administrative instruments. As such, they escape the permanent members' veto power. ${ }^{90}$ Notes are not binding, but they are outcome documents nonetheless, and therefore the product of negotiation between members. They are adopted by consensus, and are not invalidated in cases where a member dissociates itself. ${ }^{91}$ The chief working methods instrument is Note 507, which has been updated several times since its first iteration in $2006,{ }^{92}$ and was the subject of a presidential statement in 2015 , signalling a high level of commitment. ${ }^{93}$

Note 507 describes itself as a 'concise and user-friendly list of recent practices'. It has been through regular updates, and includes - amongst other things - the issues to which we now turn; chairing subsidiary bodies, and penholding. The next two sub-sections show how this sort of working methods reform is not best placed to overcome the barriers to influence discussed in the last section. The crux of the problem is that working methods deal with daily operational matters, which are often administrative and bureaucratic and, as Anne Orford has shown, offer those who undertake them little opportunity to engage in strategic decision-making. ${ }^{94}$ The languages of managerialism and bureaucracy permeate the $\mathrm{UN},{ }^{95}$ and working methods reform is a particularly fertile arena for their use. Indeed, the agenda is guided in the Security Council by echt managerial principles of "efficiency and transparency". 96

The bureaucratic pathway for influence frames Council activities as labour rather than work, in Arendt's terms. It brings with it a crescendo of administrative busywork, but scant chance for voicing alternative perspectives on acutely politicised matters. In their understandable drive to affect as wide a scope of Council activity as possible, non-permanent members sometimes risk

\footnotetext{
${ }^{90}$ UN Charter, Article 27(3)

91 Sievers and Daws, SC Procedure, 429

${ }^{92}$ UN Doc. S/2006/507 (19 July 2006 ); UN Doc. S/2010/507 (26 July 2010); UN Doc. S/2017/507 (30 August 2017)

${ }^{93}$ S/PRST/2015/19 (30 October 2015). At the open debate on the matter earlier that month, 43 non-Council states requested to participate, suggesting that the issues discussed were seen as important to the UN membership more generally, UN Doc. S/PV.7539 (20 Oct 2015)

94 Anne Orford, International Authority and the Responsibility to Protect (CUP, 2011)

${ }^{95}$ Klaas Dykmann, Jenny M. Lewis and Sune Raahede Bentzen, "When Managerialism Meets Internationalism: Administrative Reform in the United Nations in the 1970s" 37(12) International Journal of Public Administration (2014) 856-865

${ }^{96}$ UN Doc. S/2017/507, para. 1
} 
converting activities which seem ripe for work - like the drafting of outcome documents - into administrative churn. Arendt, an implacable critic of the gigantic bureaucratic machines of midtwentieth-century states, equated bureaucracy with violence; bureaucracies leave no room for argument, excluding the political thereby. ${ }^{97}$

\section{a) Chairing Subsidiary Bodies}

Most of the Council's business is done in its subsidiary bodies. ${ }^{98}$ At the time of writing, the Council had 14 sanctions committees and two committees designed to monitor and assist in the implementation of non-proliferation and counter-terrorism obligations. ${ }^{99}$ Among a handful of other standing committees, it also has 5 working groups, including one for working methods reform. The Council might be a UN political organ, but in practice it is as administrative a body as any in the UN. In this light, it is no surprise that increased administrative load is prized as evidence of increased institutional responsibility.

The labouriousness of much Council activity - particularly the kind done by non-permanent members - is nowhere more obvious than in its sub-committees. Subcommittee chairs are sought-after positions within the Council, giving non-permanent members not only status and institutional territory, but also ownership over certain issues. In theory, chairing roles ensure non-permanent members are not mere bystanders to P5 action. Here, I argue that the activities performed correspond to a particular form of labour: housekeeping. Arendt wrote about "the rise of housekeeping, its activities, problems, and organizational devices - from the shadowy interior of the household into the light of the public sphere" in the context of her concerns about "the rise of the social". 100

Arendt is routinely taken to task for her symbolic gendering of the social realm "as a scaled-up form of household". Recognising this, Patricia Owens nevertheless finds in her ideas a powerful critique of this scaled-up household: it is devastating for meaningful politics. ${ }^{101}$ For our purposes, Arendt's association of housekeeping with bureaucracy helps to reveal the withering away of politics and its substitution for pure administration. ${ }^{102}$ She associates the social with labour, life processes, with the natural world - rather than the artificed world of work. ${ }^{103}$ Housekeeping and, by extension, its scaled-up version, bureaucracy, are futile activities in Arendt's sense - their products are immediately consumed in the life process. This sort of labour is "an endless activity" that never produces a finished product. ${ }^{104}$

\footnotetext{
${ }^{97}$ Arendt On Violence, 81-87

98 UN Charter, Article 29

${ }^{99}$ Established under resolutions 1540 (2004) and 1373 (2001) respectively.

100 Arendt, The Human Condition, 38

101 Patricia Owens, "Not life but the world is at stake: Hannah Arendt on citizenship in the age of the social" 16(2)

Citizenship Studies (2012) 297-307, 297

102 Arendt, The Human Condition, 44

103 Above, at

104 Arendt, The Human Condition, 122
} 
Arendt's insights into the arduous quality of administrative work - its never-ending cycles and lack of durable product - throw doubt on the value of sub-committee chairs as a way for nonpermanent members to exert their influence. Note 507 looks like a hollow victory in this light.

In January 2017 states gathered to draft a new, comprehensive iteration of Note $507 .{ }^{105}$ Several speakers mentioned what India's representative evocatively called "the subterranean universe of the Council's subsidiary bodies". ${ }^{106}$ Still, control of these back-room venues were seen by many as a pathway to influence for non-permanent members. Compared to the Presidency of the Council, which rotates every month, annually appointed chairs seem to provide opportunity to make a more sustained impact. A second reason for the hope reposed in sub-committees is that they take decisions by consensus, which means that the permanent members are defanged of their vetoes. In the world of non-permanent members, then, there has been much enthusiasm for redistribution of these tasks. Panama, for instance, suggested that permanent members ought never to chair subsidiary bodies. ${ }^{107}$ Although France, Russia and the UK retained positions as vice chairs, Panama has more or less got its wish: The elected members distribute the chairs between them. ${ }^{108}$

In practice, however, the P5 still rule the roost - not least because of their influence over the appointment process. In 2012 working methods reformers attempted to open up the appointment process up to all Council members, encouraging them to consult the outgoing chairs and the chair of the Working Methods group. ${ }^{109}$ Moreover, although the permanent members no longer chair major committees like the Counter-Terrorism Committee, they exploit multiple pathways of influence outside the Council. ${ }^{110}$ Thirdly, the highly-involved, heavy workload of many of the Committees embroils non-permanent members in busywork, preventing them from making their mark elsewhere. Arendt's comments about the unending toil of housekeeping resonate here. Reporting fatigue is only one of the ailments associated with administrative drudgery. Committee chairs are inundated by correspondence. In 2016, nonpermanent members attempted to relieve the burden of correspondence on the sanctions committees, which see an especially heavy traffic of letters. ${ }^{111}$ The fourth and final limitation of using chairing roles as pathways to influence is that they divide the non-permanent members. Occupied as individual chairs, non-permanent members are less likely to gather round a

\footnotetext{
105 Of the incoming 2018 intake, only Poland attended this meeting.

106 UN Doc. S/PV.7616 (29 January 2016). The speaker's description is not only figurative. Committee meetings are usually held in the conference rooms, most of which are underground in the first basement of the Conference Building in New York.

${ }^{107}$ It seems Panama's concerns were taken to heart. None of the permanent members currently chairs a subsidiary body (though the UK is involved in questions relating to women, peace and security and to the protection of civilians) and they often serve as Vice-Chairs - UN Doc. S/2016/2/REV.4

108 UN Doc. S/2018/2 (2 January 2018)

109 UN Doc. S/2012/937 (17 December 2012)

${ }^{110}$ Isobel Roele, "Disciplinary Power in the UN Counter-Terrorism Committee" 19(1) Journal of Conflict and Security Law (2014) 49-84; Isobel Roele, 'Side-lining Subsidiarity: UN Security Council 'Legislation' and its Infra-Law' 79(2)

Law \& Contemporary Problems (2016) 189-214

111 UN Doc. S/2016/658 (28 July 2016)
} 
common table and work together on substantive issues. It is less likely, therefore, that they will deploy their collective potential against the permanent members.

While it is conceivable that subcommittees could produce durable work, the deck is loaded against attempts to do so. It is not enough to be in office, chairs will only make something of their office if they have a handle on the task before them. This puts a particular premium on knowing-the-ropes, and not all missions possess the requisite institutional knowledge. Sievers and Daws note that chairing roles can be very demanding, and that missions may not be able to provide the human resources needed for the task. ${ }^{112}$ It is hard enough, in other words, to maintain business-as-usual, let alone leverage the position for greater effects. The SC recognized this in 2014, accepting that chairs should be appointed "as early as possible after each election of members of the Security Council". ${ }^{113}$ Appointments ought now to be made before October, so that incoming chairs have at least 4 months' preparation time, so a proper handover can take place. $^{114}$

In a few cases, sub-committees have acted innovatively. The 1267 Committee, for example, established the Office of the Ombudsperson to the ISIL (Da'esh) and Al-Qaida Sanctions Committee to face down criticisms about the lack of due process in its listing practices. ${ }^{115} \mathrm{Can}$ we see the Office as work in Arendt's sense? Doing so is difficult because the office is itself an administrative body, very much subject to the personality of the office-holder and the zest - or otherwise - with which they carry out their mandate. ${ }^{116}$ This was stated in no uncertain terms by former Ombudsperson Kimberly Prost: "while I can state without reservation that, in practice, there is an Office which operates in a fiercely independent manner, that is attributable solely to the personalities involved". ${ }^{117}$ Administration, as those of us who inhabit university bureaucracies well know, breeds more administration, and it takes a rare individual to break that cycle.

The analogy with housekeeping helps us understand the political potential of sub-committee chairing as an activity. Although it increases non-permanent member responsibilities in a quantifiable way, it confines them to the basement drudgery of administration.

b) Penholding

An obvious way for non-permanent members to seek increased influence is in the drafting of Security Council outcome documents. Outcome documents are the telos of almost all Council

\footnotetext{
112 Sievers and Daws, SC Procedure, 129

113 UN Doc. S/2014/393 (5 June 2014)

114 UN Doc. S/2016/170

115 UN Doc. S/Res/1904 (2009).

116 Devika Hovell, The Power of Process (OUP, 2016)

117 Remarks by Kimberly Prost, Ombudsperson, Security Council Al-Qaida Sanctions Committee, to the 49th meeting of the Committee of Legal Advisors on Public International Law (CAHDI) of the Council of Europe (Strasbourg, 20 March 2015). Available at:

https://www.un.org/sc/suborg/sites/www.un.org.sc.suborg/files/cahdi.pdf
} 
activity - as they are in almost any organisation. ${ }^{118}$ Achieving agreement on a text is no mean feat, and those proposing initiatives feel a great sense of accomplishment when agreement is reached. ${ }^{119}$ The practice of negotiating documents seems to come closer to "work" in Arendt's sense of the word. Council documentation is both paper-pushing and world-building. Although the Council's bricks and mortar world is centred on the second and third floors of the UN Conference Building in Manhattan, it is also an archival world - the sum of its official documentation. The materiality of this world is obscured by the migration of the Dag Hammarskjold Library online, and the partial shuttering of its physical premises. ${ }^{120}$

To what extent, then, can non-permanent members contribute to this area of Council activity? Non-permanent members often use their presidency to push for statements on a thematic issues like children and armed conflict, or the rule of law. Presidential statements can be a stepping stone, many terms down the line, to a resolution. This long-game can only be played, however, by states which are in a position to serve multiple terms on the Council, and - as we have seen this privilege is not equally open to all states. ${ }^{121}$ Quicker effects can be had if a non-permanent member can gain ownership over an issue by becoming the penholder for it. Accordingly, penholding is a fiercely contested matter, and one of the main sites of struggle in Note 507.

The penholder has responsibility for drafting outcome documents on a specific issue, including resolutions, presidential statements, notes, letters and press statements. Not only is the penholder responsible for producing the text of drafts to be debated, it can also call meetings, and arrange visiting missions and briefings. In this way, the penholder can exert enormous control over a situation on the Council's agenda (or an aspect thereof), or of one of its thematic areas. Penholding is a relatively recent phenomenon in its current form, ${ }^{122}$ which has, thus far, been dominated by the P3 on the grounds that the complexity of the situations on the Council's agenda demands "a depth of expertise and a large staff". ${ }^{123}$ France is penholder for most of the situations involving Francophone Africa; the UK holds the pen for major thematic issues of peacekeeping and the protection of civilians, not to mention country situations including Yemen, Sudan, Libya and Colombia. The US leads on counterterrorism in all its forms, and on South

\footnotetext{
118 Annelise Riles comments that for bureaucrats, a meeting without an output is an illegitimate meeting. "Outputs: the promises and perils of ethnographic engagement after the loss of faith in transnational dialogue" Journal of the Royal Anthropological Institute (2017) 183-198, 187

119 Annelise Riles also notes a slightly different affective dimension of UN documentation. "Each document, each survey, each position paper is the product of countless others, and for a while, at least, until the feeling fades into frustration, this imbues the events with a weightiness that is almost dwarfing" ("Models and Documents", 812). ${ }^{120}$ Half of the Library Building - the side that constitutes the campus' South perimeter wall - has been closed down for security reasons.

121 Above, s. 2(b)

${ }^{122}$ Sievers and Daws, SC Procedure, Ch.5, Section 6 online update, "The "lead country" or "penholder" practice for drafting outcome documents" (18 August 2018). Available at: https://www.scprocedure.org/chapter-5-section-6b ${ }^{123}$ Sievers and Daws, SC Procedure, Ch.5, Section 6 online update, "A historical overview of the "lead country" or "penholder" practice" (19 August 2018). Available at: https://www.scprocedure.org/chapter-5-section-6c
} 
Sudan, DPRK, Iran and, de facto, the Middle East. ${ }^{124}$ As Bolivia's representative recently complained, "it is the permanent members who are the penholders almost exclusively". ${ }^{125}$

"Penholding" is a millennial neologism, but the exclusive and exclusionary nature of the drafting process has been a long-standing issue in the Council. States were ticked-off for their cliquey practices in a Presidential Note in $1999 .{ }^{126}$ Nevertheless, there seems to have been a step-change since the 2000s. As Ian Martin recently told the Council, "Member States that have returned to the Council after a decade or more of absence have noted the closing down of space for initiatives of elected members". ${ }^{127}$

Note 507 formally recognized penholding as "an informal arrangement", ${ }^{128}$ and took steps to make the practice more inclusive. ${ }^{129}$ This is no small achievement. When in 2012 Portugal began the process of drafting a Presidential Note to address the issue, it proved such a hot potato that the approved text ended up expunging any mention of penholding. ${ }^{130}$ Eventually Note 507 broached the issue, providing that any member may act as penholder, and that all members are encouraged to do so - including as co-penholders. ${ }^{131}$ Drafting is done according to a "silence procedure", by which members are given a specific length of time to consider a draft and raise objections. ${ }^{132}$ This system favours states with large, experienced staffs who can react immediately to rapidly evolving events in complex situations. Elected members including Peru and Ethiopia speaking in the February 2018 open debate emphasized the importance of consultations. Equatorial Guinea was more forthright still, stating that consultation

"frequently does not happen. The permanent members prepare the drafts, consult each other and finalize the process with very little time for discussion. When elected members wish to make comments or suggestions, the deadline has passed and there is no time to incorporate new suggestions, which means that non-permanent members have only two options - accepting a fait accompli and finding a reason to vote in favour; or abstaining or voting against, since sometimes they agree with the substance of the issue but not with the language used". ${ }^{133}$

Australia and Luxembourg's tenacious efforts on the humanitarian issues in Syria during their 2013-14 term provides a counter-example to the impression that permanent members control the drafting process. They were joined by Jordan in the next intake, who held the pen in 2015. Since then, a rolling cast of other states have been joint holders of the pen as the original states

\footnotetext{
124 Security Council Report published an invaluable list of penholders as of January 2018, available here: https://www.securitycouncilreport.org/un-security-council-working-methods/pen-holders-and-chairs.php 
graduated from the Council at the end of their two year terms: Egypt, New Zealand, Spain, Japan, Sweden and Kuwait have all been involved. This is not merely co-penholding; it is successive pen-holding. Unlike chairships, which give states an administrative monopoly over a particular area, penholding seems to encourage cooperative ventures and collective action. States worked together to relieve the humanitarian crisis in Syria, their successive and imbricated efforts were more like a workshop than a conveyer-belt, with new states apprenticed to retiring ones.

The states did not just inherit a role, they have worked on the same project. Overlapping handovers see to the problem of continuity, and the episode redounds with joint effort. While the solutions crafted by these states are far from perfect, they led to tangible changes on the ground, including securing Syrian government consent for humanitarian access. ${ }^{134}$ This penholding activity was not mere busy-work. The non-permanent members' 2018 commitment to increased interaction is a positive step in this regard. ${ }^{135}$ The position of group coordinator (which rotates every month), the sharing of draft documents, and the regular meetings at permanent representative and political coordinator levels contain a promise of collective action.

This is not to say that all penholding is necessarily work because it is directed, at least nominally, to the passage of outcome documents. The recognition of penholding in Note 507 risks making penholding into an office, which would become, like chairing subsidiary committees, mainly administrative. In other words, it would be an office held for status and managerial convenience, rather than effect. This danger is less a function of non-permanent members' capacities, than the current logic of distribution that governs the allocation of penholding responsibilities - empty slots must be filled. Sara Ahmed's insights into performance culture help us here. ${ }^{136}$ The appointment itself is the performance - not the work that may be generated as a result. In this way the redistribution of chairs and pens in the Council can be seen as a sort of nonperformative performance of inclusivity, in Ahmed's sense. She explains how a commitment to inclusion, like the one made in Note 507, can perform "the appearance of bringing something into effect", which can be a way of "preserving the past". ${ }^{137}$ The non-permanent members "get stuck", to use Ahmed's apt expression, in the basement rooms of the Conference Building.

The language of penholding, moreover, seems to grease the slide from work into labour. The writer works; but the holder of the pen is more redolent of the order of the bath. It takes us back into the world of bureaucratic ceremony and protocol, masking the labour of administration with the pomp and circumstance of title.

Penholdership is a management technique for the process of drafting outcome documents. Penholders galvanise commitment and organise the technicalities of putting together a draft text. Drafting used to be a matter of authorship - albeit fraught with technicality. As Riles put it, drafting negotiated documents "is a detailed, labour-intensive building-block" affair. "One slowly

\footnotetext{
134 UN Doc. S/Res/ 2165 (2014)

135 Above, at (and see Sievers and Daws, SC Procedure: Online Update to Ch. 3, s. 3 (10 December 2018). Available at: https://www.scprocedure.org/chapter-3-section-3i)

136 Sara Ahmed, On Being Included (Duke, 2012), Chapter 3. See also Chapter 4 on the concept of non-performatives.

137 Ahmed, On Being Included, 126
} 
pieces the text together, phrase by phrase, heading by heading". ${ }^{138}$ For all its technicality this process has not lost its character as work. The French translation of "original mover", the phrase used in the Council's Rules of Procedure, is not quite apt, to be sure. ${ }^{139}$ Riles' work on drafting documents in the UN troubles the way international lawyers often treat such documents as though there was a single consciousness which meant something by the text. The current French term for penholders, by contrast, is redacteurs. ${ }^{140}$ The function comes closer to the artisanal sense of work, enabling us to distinguish it from art work. Indeed, the idea that several people come together around a single table to produce a durable object resonates with the original styling of the UN as a "workshop for peace". ${ }^{41}$

\section{Transformation and Renewal}

As a strategy to transform the Security Council, working methods reform is logical but flawed. Although it increases the nominal status of non-permanent members by giving them administrative roles, it thereby ensnares them in the non-performative busy-work of administration. Instead of renewing the Council through their durable contributions, nonpermanent members end up as interchangeable cogs in the Council's administrative machinery.

This is particularly clear in the characteristically managerial inclusion of new member training as part of Note $507 .^{142}$ The approach to socializing new members - "transitional arrangements"143 is very much about socializing newcomers into an existing culture, rather from letting new members bring a refreshing diversity to the body. The transition, in other words, is a one-way street. Non-permanent members are not expected to add their own rhythm to Council affairs, but to get themselves "up to speed" with the Council's furious tempo. ${ }^{144}$ The non-permanent members who have fared best have tended to be from the Global North - like Australia, as already mentioned, or Germany, which succeeded in bifurcating the work of the al Qaeda and Taliban Sanctions Committee during its 2012-12 term. ${ }^{145}$

The impression that the work culture is one of fast-paced administration is reinforced by one of the major training events for new members, the Hitting-the-Ground-Running workshop organised by Finland, in collaboration with Columbia University and the Security Council Affairs Division, every November. Sessions are called things like "taking stock and looking ahead", ${ }_{146}$ and

\footnotetext{
138 Annelise Riles, "Models and Documents: Artefacts of International Legal Knowledge" 48(4) ICLQ (1999) 805825; Annelise Riles, The Network Inside Out (University of Michigan Press, 2000)

139 The term is used in Rules 32 and 35 of the Council's Provisional Rules of Procedure

140 The distinction is made by Sievers and Daws, SC Procedure: Online Update Available at:

https://www.scprocedure.org/chapter-5-section-6b

${ }^{141}$ In the words of its chief architect, Wallace K. Harrison. See George A. Dudley, $A$ Workshop for Peace (MIT Press, 1994)

142 UN Doc. S/2017/507, paras. 140-142

143 UN Doc. S/2016/619 (15 July 2016)

144 Above, at

145 As discussed in John Langmore and Ramesh Thakur, "The Elected but Neglected Security Council Members"

39(2) The Washington Quarterly (2016) 99-114, 108

146 UN Doc. S/2017/468 (1 June 2017)
} 
members trade "lessons learned" and "best practices". ${ }^{147}$ Such training is the equivalent of limbering up for a big race. Participation is strictly competitive, and the permanent members are the ones to beat. The platforms on which incoming members were elected by their regional groupings are a sideshow. The main event is simply keeping up. Under these circumstances, only the most seasoned and best prepared of incoming members could hope to make something of their office, and even then they are seriously hindered by the existing agendas of the P5. ${ }^{148}$

The obduracy of the P5 has driven some states to act outside the Council by joining together in Groups of Friends created to deal with a particular situation on the Council's agenda or, thematic issues like Women, Peace, and Security. As Jochen Prantl, who has written extensively on the phenomenon, explains, such groups are informal arrangements which operate outside the Council. ${ }^{149}$ Although this constitutes a pathway to enduring influence for a particular member state, it does not have a transformative effect on the Council itself.

Groups of Friends, as Prantl illustrates with his example of the Western Contact Group on Namibia (Canada, France, Germany, UK, and USA), are often brought together "to escape those structural deficiencies [of the Council] and to work outside the UN framework". ${ }^{150}$ The tactic has been used by several non-permanent member states to make progress on particular issues. For instance, Australia's involvement in the work of the Core Group on East Timor, and Canada's involvement in the Core Group of Friends of Haiti. ${ }^{151}$ Groups of Friends have also been used by the permanent members. Russia's involvement in the Group of Friends for Georgia, the socalled "P5+1" group of states which negotiated with Iran over its nuclear programme, or the Group of Friends of Libya, which included France, the UK and the USA, among many others. ${ }^{152}$ Often the act of stepping out of the Council yields complementary action, but sometimes, as in the extreme examples of Operation Allied Force or Operation Iraqi Freedom, it is a way of bypassing the Security Council. ${ }^{153}$ In any case, the tactic of stepping outside the Council was already being questioned in the early 1990s, when Secretary General Boutros Boutros-Ghali warned that although such groups can make valuable contributions, they lead to confused lines of responsibility and effort. ${ }^{154}$

147 The first session of the Hitting the Ground Running workshop in 2017, for example, asked "Which benchmarks should be employed to gauge the extent to which the Council has or has not been successful over the past year?" (p. 6) and "Are there implementation steps that should be regarded as priorities for the coming year?" (p. 8), UN Doc. S/2017/468 (1 June 2017)

148 These are discussed by Langmore and Farrall's in their analysis of Australia's 2013-14 term, John Langmore and Jeremy Farrall, "Can Elected Members Make a Difference in the UN Security Council? Australia's Experience in 2013-2014” 22 Global Governance (2016), 59-77

${ }^{149}$ Jochen Prantl, The UN Security Council and Informal Groups of States (OUP, 2006)

150 Jochen Prantl, "Informal Groups of States and the UN Security Council" 59(3) International Organization (2005) 559-592, 575

${ }^{151}$ See generally, Theresa Whitfield, Friends Indeed?: The United Nations, Groups of Friends, and the Resolution of Conflict

(United States Institute of Peace Press, 2007), Chapter 7

152 UN Doc. S/Res/1973 (2011)

${ }^{153}$ Jules Lobel and Michael Ratner, "Bypassing the Security Council: Ambiguous Authorizations to Use Force, Ceasefires and the Iraqi Inspection Regime" 93(1) American Journal of International Law (1999) 124-154

${ }^{154}$ Boutros Boutros Gahli, Supplement to the Agenda for Peace, UN Doc. A/50/60 - S/1995/1 (1995), paras 83-84 
Although by no means all the states involved in Groups of Friends are from the global North the Core Group for Haiti includes Latin American states like Brazil, and the Group of Friends for Libya includes a number states in the Middle East - it has been suggested that the tactic of leaving the Council to gain influence is limited to the richest, biggest, and best connected states. This certainly seems to be borne out by the use of the tactic by the P5. As Theresa Whitfield explained, Groups of Friends are used by already dominant states to assert "elite ownership of specific issues". ${ }^{155}$ We might question, indeed, how renewing the rolling involvement of all these states from the Global North really is, especially when the success of Groups of Friends is often down to "the deep pockets of the international donor community". ${ }^{156}$

Contrasting working methods reform with Groups of Friends as a pathways to influence brings out the potential in the former. Where working methods reform could transform the Council, these groups seek influence by by-passing the Council; where working methods reform can be inclusive and can promote diversity, groups tend to be dominated by states from the Global North or by emerging powers like Brazil. They specifically take politics outside the Council, and while they involve a gathering of states, they do not come together around the same chairs and the same table, as Arendt put it. ${ }^{157}$ Working methods reform surely promises a more progressive tactic for change if only because it promises to change how the Council works, not just what the Council achieves.

In this respect, Groups of Friends can be contrasted with interventions that take place outside the Council's formal administrative structures, but with a view to changing the Council's working practices. Non-permanent members' increasing willingness to come together as a group and harness their collective influence is a promising development. Sievers and Daws report that in September 2018, incumbent and incoming members gathered to agree Ten Elements for Enhanced E10 Coordination and Joint Action, ${ }^{158}$ which was agreed outside the institutional framework. In doing so, the non-permanent members stepped outside formulaic pathways to influence, but came together in order to harness the potential of their collective power.

What prospect is there of a more diverse Council? How can the renewing possibilities of the non-permanence of two-thirds of its membership be harnessed? At the beginning of this article, I acknowledged that renewal was not sufficient for political action in Arendt's sense. A positive diversity of decision-making may be too much to hope for. Instead, I suggested that a negative politics of difference might be possible. What would this look like?

Non-identity thinking is at the heart of negative dialectics, Adorno's answer to the possibility of post-Enlightenment politics. Non-identity thinking is the polar opposite of the working methods

\footnotetext{
155 Teresa Whitfield, "Groups of Friends" in D. Malone (ed.), The UN Security Council: From the Cold War to the 21st Century (Lynne Rienner, 2004), 320

156 Whitfield, "Groups of Friends", 319

157 Above, at

158 Sievers and Daws, SC Procedure: Online Update to Ch. 3, s. 3 (10 December 2018). Available at:

https://www.scprocedure.org/chapter-3-section-3i
} 
reformers desire to ensure "continuity in the work of the Council". ${ }^{159}$ It makes the renewing effect of the non-permanent members into a not-like-that, rather than a like-this. Nonpermanent members, then, can go against the Council grain in order to leave their mark. Recognizing the superfluity of administrative responsibilities, ${ }^{160}$ may enable them - in Susan Marks' lovely phrase - to cultivate an "in-the-wayness"; ${ }^{161}$ not sabotage, but not business-asusual either. Instead of falling into step, non-permanent members should cultivate a syncopated approach to the terms they serve. In doing so, the members remain within the framework of the Council, but as a disruptive presence. In this negative sense, they insist on the diversity of being together in the Council. States come together around the same horseshoe table, but they meet in all their difference.

Seen in this light, Kazakhstan's flag installation ceremony takes on a new significance. Rather than performing the non-performativity of administration, we can see it as a performance of inthe-wayness. Slap-bang in the middle of the second floor corridor of the Conference Building, the ceremony hijacked the press stakeout area - a space of high politics and global attention. The ceremony was in the way. We can read it as a statement of presence that materialised diversity. In taking over the physical space of the Council, the incoming members of the Council came together and asserted themselves, rather than politely tip-toing around the permanent members, or rushing to keep up-to-speed with them. If we see these states as asserting their unlikeness, rather than their likeness, the ceremony becomes a performance not of the elevated status of the new members, but of renewing the Security Council - of difference in the corridors of power.

159 UN Doc. S/2016/619 (Note by the President of the Security Council, 15 July 2016

160 Arendt discusses superfluity in The Origins of Totalitarianism (Penguin, 2017), notably, but not exclusively in relation to concentration camps. The first "superfluous men" she identifies are the Boers (246). Housekeeping and superfluity are not the same thing in Arendt's work, but they have in common the fact that both are "work performed without product" (599). Moreover, the gendered nature of housekeeping suggests an othering which, while not on a par with the absolute othering of superfluity, speaks to the way the E10 have been hived-off from the P5, and treated as lower-orders.

${ }^{161}$ Susan Marks, "Law and the Production of Superfluity" 2(1) Transnational Legal Theory (2011) 1-24, 24 